\title{
Profil pioderma pada anak di Poliklinik Kulit dan Kelamin RSUP Prof. Dr. R. D. Kandou Manado periode tahun 2013-2015
}

\author{
${ }^{1}$ Priscilia F. Lumataw \\ ${ }^{2}$ Herry Pandaleke \\ ${ }^{2}$ Pieter L. Suling \\ ${ }^{1}$ Kandidat Skripsi Fakultas Kedokteran Universitas Sam Ratulangi Manado \\ ${ }^{2}$ Bagian Ilmu Kesehatan Kulit dan Kelamin Fakultas Kedokteran \\ Universitas Sam Ratulangi Manado \\ Email: fransisca.lumataw@ hotmail.com
}

\begin{abstract}
The skin can easily affected by the external environment and continues to change due the adaption to environmental condition, triggering infection of the skin. Pyoderma is the most common skin infection in infants and children. Pyoderma is a skin disease that caused by Staphylococcus, Streptococcus, or both. Pyoderma oftenly found in developing countries, especially the tropic areas. Pyoderma is one of four disease that have the highest number of outpatient visits in Indonesia. High incidence of pyoderma in children in developing countries, leading to a need for periodic evaluation of morbidity pyoderma. This descriptive retrospective study aimed to identify the gender, age, type of pyoderma, and therapy in children with pyoderma in Poliklinik Kulit dan Kelamin Prof. Dr. R. D. Kandou Manado year period 2013-2015. The number of new cases in children with pyoderma is 114 cases $(14,88 \%)$, oftenly found in males and 1-4 years age group $(49,12 \%)$. The diagnosis of impetigo krustosa is the most finding type of pyoderma and the most commontly given therapy is a combination therapy of systemic antibiotics with topical $(73,68 \%)$. Erythromycin is the most common drug that used orally and fusidic acid as topical.
\end{abstract}

Keywords: pyoderma, children

\begin{abstract}
Abstrak: Kulit mudah terpengaruh oleh lingkungan luar dan terus mengalami perubahan karena beradaptasi dengan perubahan lingkungan, sehingga memicu infeksi pada kulit. Pada bayi dan anak, infeksi kulit yang paling sering didapatkan adalah pioderma. Pioderma ialah penyakit kulit yang disebabkan oleh bakteri Staphylococcus, Streptococcus atau oleh keduaduanya. Pioderma merupakan jenis penyakit kulit yang paling sering didapatkan di negaranegara berkembang, terutama daerah tropis. Pioderma menempati urutan empat besar jumlah kunjungan rawat jalan di Indonesia. Kejadian pioderma tinggi pada anak di negara berkembang membuat perlunya evaluasi secara berkala morbiditas pioderma. Penelitian retrospektif deskriptif ini bertujuan untuk mengidentifikasi jenis kelamin, usia, jenis pioderma, dan terapi pada anak yang menderita pioderma di Poliklinik Kulit dan Kelamin RSUP Prof. Dr. R. D. Kandou Manado periode tahun 2013-2015. Jumlah pasien kasus baru pioderma pada anak sebanyak 114 kasus $(14,88 \%)$, dengan terbanyak pada jenis kelamin laki-laki dan kelompok umur 1-4 tahun (49,12\%). Diagnosis impetigo krustosa adalah jenis pioderma terbanyak yang ditemukan dan terapi yang paling sering diberikan adalah pemberian terapi kombinasi antara antibiotik sistemik dengan topikal $(73,68 \%)$. Golongan eritromisin merupakan antibiotik sistemik tersering yang digunakan dan asam fusidat merupakan antibiotik topikal yang paling sering diberikan.
\end{abstract}

Kata kunci: pioderma, anak 
Tubuh memiliki berbagai macam sistem pertahanan untuk melindungi diri dari berbagai macam mikroba asing, baik sistem pertahanan internal yang berkaitan dengan imunitas maupun sistem pertahanan eksternal seperti kulit. Kulit merupakan organ terbesar tubuh yang memiliki fungsi sebagai sawar mekanis antara lingkungan eksternal dan jaringan dibawahnya. Karena pertahanan yang terus menerus kulit mudah terpengaruh oleh lingkungan luar dan terus mengalami perubahan karena selalu beradaptasi dengan perubahan lingkungan. Hal itu dapat memicu infeksi pada kulit. ${ }^{1,2}$

Berdasarkan umur, infeksi kulit lebih mudah terjadi pada bayi dan anak dibandingkan dengan dewasa. Hal ini dikarenakan kulit bayi dan anak memiliki perbedaan apabila dibandingkan dengan kulit orang dewasa. Walaupun struktur sudah lengkap, namun berbeda dalam maturitas dan fungsinya. Kulit bayi dan balita lebih tipis, jaringan antar sel lebih longgar, serta sistem pertahanan tubuh alamiah dan adaptif di kulit belum cukup matang, menyebabkan kulit dan fungsi proteksi terhadap infeksi lemah. ${ }^{3}$

Pada bayi dan anak, infeksi kulit yang paling sering didapatkan adalah pioderma. Pioderma ialah penyakit kulit yang disebabkan oleh bakteri Staphylococcus, Streptococcus atau oleh kedua-duanya. Sedangkan Staphylococcus epidermidis adalah bakteri penghuni normal kulit yang jarang menyebabkan infeksi tetapi dapat juga menyebabkan infeksi superfisial dan invasif. $^{4}$

Pioderma merupakan jenis penyakit kulit yang paling sering didapatkan di negara-negara berkembang, terutama daerah tropis. Sebuah laporan yang ditulis Bowen berdasarkan 18 studi prevalensi populasi umum di negara-negara berkembang pada tahun 2015 menunjukkan prevalensi tinggi untuk infeksi kulit (2187\%). Dalam penelitian Bowen tersebut pioderma adalah penyakit yang paling sering ditemukan pada anak (0,2-35\%). ${ }^{5}$ Pioderma menempati urutan empat besar jumlah kunjungan rawat jalan di Indonesia. Pioderma pada anak memiliki tingkat prevalensi lebih tinggi dari dewasa (terutama anak dibawah 5 tahun). ${ }^{5,6}$

Pada September 2014, menurut data dari penelitian Azizah, pasien terbanyak yang datang ke RS Karitas Sumba adalah anak-anak (66,7\%) dengan diagnosis penyakit infeksi pada kulit $(57,7 \%){ }^{7}$ Studi oleh Dewi di RSU Dr. Soetomo Surabaya periode Januari 2002-Desember 2006 mendapatkan pioderma sebagai salah satu dari lima penyakit kulit terbanyak pada anak, dengan kelompok usia yang paling banyak menderita pioderma yaitu 1-4 tahun. ${ }^{6}$

Data insiden pioderma di Poliklinik Kulit dan Kelamin RS Sanglah Denpasar yang dilaporkan Laksmi, selama periode Januari 2006-Desember 2008 menunjukkan 6,5\% (287 kasus), 6,23\% (267 kasus), 4,5\% (175 kasus). ${ }^{8}$

Di Poliklinik RSUP Prof. Dr. R.D. Kandou Manado, Harahap melaporkan tahun 2009-2011 pioderma pada anak merupakan infeksi kulit yang paling sering dengan jumlah 151 kasus $(25,38 \%) .{ }^{9}$ Pada tahun 2012 di RS yang sama, Pangow melaporkan jumlah pasien anak dengan pioderma berjumlah 53 kasus $(16,51 \%){ }^{10}$

Kejadian pioderma tinggi pada anak di negara berkembang termasuk Indonesia, sehingga perlu dievaluasi secara berkala morbiditas pioderma. Penelitian ini bertujuan untuk mengidentifikasi jenis kelamin, usia, jenis pioderma, dan terapi pada anak yang menderita pioderma di Poliklinik Kulit dan Kelamin RSUP Prof. Dr. R. D. Kandou Manado periode tahun 2013-2015.

\section{METODE PENELITIAN}

Penelitian ini dilakukan secara retrospektif deskriptif dengan mengambil data dari catatan rekam medik pasien di Instalasi Rekam Medik dan Buku register di Poliklinik Kulit dan Kelamin RSUP Prof. Dr. R. D. Kandou Manado. Populasi dari penelitian ini adalah semua pasien baru yang datang di Poliklinik Kulit dan Kelamin RSUP Prof. Dr. R. D. Kandou Manado. Sampel adalah semua pasien baru yang terdiagnosa dengan pioderma pada 
usia 0 - 14 tahun. Variabel penelitian yaitu jenis kelamin, umur, jenis pioderma, dan terapi.

Data yang sudah terkumpul diolah, disusun, dan disajikan dalam bentuk tabel dan dianalisis berdasarkan hasil presentase.

\section{HASIL PENELITIAN}

Berdasarkan penelitian yang dilakukan di Poliklinik Kulit dan Kelamin RSUP Prof. Dr. R. D. Kandou Manado Tahun 2013-2015 didapatkan jumlah keseluruhan pasien yang berobat adalah sebesar 3573 pasien, 766 diantaranya adalah pasien anak dan $14,88 \%$ didiagnosis dengan pioderma pada anak (Tabel 1). Pioderma pada anak tertinggi pada tahun $2013(17,34 \%)$.

Tabel 1. Distribusi kunjungan pasien pioderma pada anak

\begin{tabular}{llcc}
\hline Tahun & $\begin{array}{c}\text { Total } \\
\text { kunjungan } \\
\text { pasien anak }\end{array}$ & $\begin{array}{c}\text { Total } \\
\text { kunjungan } \\
\text { pasien } \\
\text { pioderma pada } \\
\text { anak }\end{array}$ \\
\hline 2013 & 346 & 60 & $(17,34 \%)$ \\
2014 & 232 & 35 & $(15,09 \%)$ \\
2015 & 188 & 19 & $(10,11 \%)$ \\
Total & 766 & 114 & $(14,88 \%)$ \\
\hline
\end{tabular}

Distribusi jenis kelamin pasien pioderma dari tahun 2013-2015 terbanyak pada laki-laki $(63,16 \%)$ (Tabel 2).

Tabel 2. Distribusi pasien pioderma pada anak menurut jenis kelamin

\begin{tabular}{ccc}
\hline Tahun & Laki-laki & Perempuan \\
\hline $\mathbf{2 0 1 3}$ & 36 & 24 \\
$\mathbf{2 0 1 4}$ & 25 & 10 \\
$\mathbf{2 0 1 5}$ & 11 & 8 \\
Total & $72(63,16 \%)$ & $42(36,84 \%)$ \\
\hline
\end{tabular}

Usia terbanyak didapatkan pada kelompok umur 1-4 tahun $(49,12 \%)$ (Tabel 3 ). Jenis pioderma terbanyak ialah impetigo krustosa $(39,47 \%)$ (Tabel 4). Terapi kombinasi merupakan terapi yang paing banyak diberikan $(73,68 \%$ ) (Tabel 5).

Antibiotik sistemik yang paling banyak digunakan pada anak ialah antibiotik golongan eritromisin, yaitu $67,5 \%$ (Tabel 6). Antibiotik topikal yang paling banyak digunakan ialah Asam Fusidat sebanyak $(52,63 \%)$ (Tabel 7).

Tabel 3. Distribusi pasien pioderma pada anak tahun 2013-2015 menurut umur

\begin{tabular}{ccc}
\hline Umur & Total & Persentase \\
\hline$<1$ tahun & 14 & $12,28 \%$ \\
1-4 tahun & 56 & $49,12 \%$ \\
5-14 tahun & 44 & $38,60 \%$ \\
\hline
\end{tabular}

Tabel 4. Distribusi jenis pioderma pada pasien anak

\begin{tabular}{lcc}
\hline \multicolumn{1}{c}{ Jenis Pioderma } & Total & Persentase \\
\hline Impetigo Krustosa & 45 & $39,47 \%$ \\
Impetigo Bulosa & 14 & $12,28 \%$ \\
Furunkel & 21 & $18,42 \%$ \\
Karbunkel & 1 & $0,88 \%$ \\
Folikulitis & 24 & $21,05 \%$ \\
Selulitis & 2 & $1,75 \%$ \\
Erisipelas & - & $0 \%$ \\
Ektima & 7 & $6,14 \%$ \\
\hline
\end{tabular}

Tabel 5. Distribusi farmakoterapi pada pasien pioderma anak

\begin{tabular}{lcc}
\hline \multicolumn{1}{c}{ Terapi } & Total & Persentase \\
\hline $\begin{array}{l}\text { Terapi Kombinasi } \\
\text { (antibiotik sistemik }\end{array}$ & 84 & $73,68 \%$ \\
+antibiotik topikal) & & \\
Antibiotik Sistemik & 11 & $9,65 \%$ \\
Antibiotik Topikal & 19 & $16,67 \%$ \\
\hline
\end{tabular}

Tabel 6. Distribusi penggunaan antibiotik sistemik pada pasien pioderma anak

\begin{tabular}{lcc}
\hline \multicolumn{1}{c}{ Antibiotik } & Total & Persentase \\
\hline Sefadroksil & 13 & $11,4 \%$ \\
Klindamisin & 1 & $0,88 \%$ \\
Amoksisilin & 2 & $1,75 \%$ \\
Eritromisin & 77 & $67,5 \%$ \\
Cefixime & 2 & $1,75 \%$ \\
\hline
\end{tabular}

Tabel 7. Distribusi penggunaan antibiotik topikal pada pasien pioderma anak

\begin{tabular}{lcc}
\hline \multicolumn{1}{c}{ Antibiotik } & Total & Persentase \\
\hline Asam Fusidat & 60 & $52,63 \%$ \\
Mupirosin & 23 & $20,18 \%$ \\
Gentamisin & 20 & $17,54 \%$ \\
\hline
\end{tabular}




\section{BAHASAN}

Pada penelitian ini, sampel yang diambil adalah seluruh pasien kasus baru dengan diagnosa klinis pioderma pada anak yang datang berobat di Poliklinik Kulit dan Kelamin RSUP Prof. Dr. R. D. Kandou Manado tahun 2013-2015 berdasarkan data pasien pada buku register dan catatan rekam medik.

Keseluruhan total kunjungan pasien anak dari tahun 2013 sampai 2015 di Poliklinik Kulit dan Kelamin RSUP Prof. DR. R. D. Kandou Manado adalah 766 kasus dan 114 diantaranya merupakan penderita pioderma pada anak $(14,88 \%)$.

Pada tahun 2013 ditemukan 17,34\%, tahun 2014 ditemukan 15,09\%, dan tahun 2015 10,11\%. Pada RS yang sama tahun 2009-2011, Harahap melaporkan angka kejadian pioderma pada anak mencapai $25,38 \%$ dan tahun 2012 Pangow melaporkan angkanya menjadi 16,51\%.9,10

Apabila dibandingkan, dari tahun ke tahun angka penderita pioderma pada anak mengalami penurunan. Hal ini salah satunya mungkin disebabkan oleh karena sejak tahun 2014 BPJS Kesehatan mulai diberlakukan. Dalam program BPJS, pioderma termasuk dalam daftar 155 penyakit yang wajib ditangani oleh fasilitas kesehatan 1 (klinik, puskesmas, dokter praktik). Penyakit-penyakit yang masuk dalam daftar tersebut tidak boleh dirujuk, kecuali mengalami komplikasi yang parah. ${ }^{11}$ Sehingga pasien pioderma yang ditangani di RS semakin berkurang. Selain itu pada 2010, Santos mengatakan dalam sebuah studi di Timor Leste, masyarakat negara berkembang cenderung menganggap penyakit kulit tidak perlu mendapatkan perhatian karena tidak berbahaya, tidak mengancam jiwa, dan tidak perlu penanganan secepatnya. ${ }^{12}$ Padahal berdasarkan studi oleh Hazarika dari Department of Dermatology, Tagore Medical College and Hospital pada tahun 2012, anak dengan pioderma memiliki resiko tinggi mengidap penyakit acute renal failure dan acute poststreptococcal glomerulonephritis. ${ }^{13}$

Pada Tabel 2, data distribusi menurut jenis kelamin menunjukkan pioderma pada anak lebih banyak ditemukan pada laki-laki dibandingkan perempuan. Dari tabel tersebut distribusi jenis kelamin pasien pioderma pada laki-laki berjumlah 72 orang $(63,16 \%)$ dan pada perempuan berjumlah 42 orang $(36,84 \%)$. Hal ini sebanding dengan penelitian oleh Department of Microbiology, Nigeria tahun 2015 yang menemukan bahwa laki-laki memliki prevalensi lebih tinggi daripada perempuan untuk mengalami infeksi kulit oleh bakteri, dimana diantaranya pioderma, dengan masing-masing berbanding $80,4 \%$ dan $67,2 \%{ }^{14}$ Temuan yang sama juga datang dari Western Nigeria dimana pioderma lebih banyak ditemukan pada laki-laki. ${ }^{15,16}$ Di Indonesia, studi oleh Dewi di RSU Dr. Soetomo Surabaya periode Januari 2002Desember 2006 menemukan bahwa pioderma paling banyak diderita oleh lakilaki. ${ }^{6}$

Hal ini berbeda dengan penelitian oleh Pangow di Poliklinik Kulit dan Kelamin RSUP Prof. Dr. R. D. Kandou Manado periode tahun 2012, dimana pada penelitian tersebut menunjukkan pioderma terbanyak pada perempuan $(56,6 \%){ }^{10}$

Hasil temuan dimana laki-laki lebih banyak menderita pioderma bisa disebabkan fakta bahwa pada usia prasekolah anak perempuan cenderung bermain di dalam rumah dan tidak suka kotor. Berbeda dengan anak lelaki yang senang bermain diluar rumah dan tidak memperhatikan kebersihan diri. Selain itu, remaja perempuan lebih sadar penampilan mereka dan sebagai hasilnya mereka lebih peduli terhadap kebersihan pribadi dibandingkan dengan laki-laki. Hal itu mungkin ditanamkan sejak dini oleh orang tua kepada anak perempuan.

Tabel distribusi umur pasien pioderma pada anak (tabel 3) memperlihatkan bahwa usia terbanyak yaitu pada kelompok umur 1-4 tahun sebanyak 56 orang $(49,12 \%)$, diikuti dengan kelompok umur 5-14 tahun sebanyak 44 orang $(38,60 \%)$ dan kelompok umur $<1$ tahun yang paling sedikit, sebanyak 14 orang $(12,28 \%)$. Temuan ini sesuai dengan penelitian oleh Gandhi di 
Department of Microbiology, Gajra Raja Medical College, India tahun 2012 yang dipublikasikan oleh North American Journal of Medical Sciences dimana prevalensi rentang umur pasien pioderma yang paling banyak yaitu $<10$ tahun dengan jumlah kasus 98 (48\%) dari total 200 kasus yang diteliti. ${ }^{17}$ Penelitian yang dilakukan tahun 2012 oleh Pangow di Poliklinik Kulit dan Kelamin RSUP Prof. Dr. R. D. Kandou Manado juga menunjukkan hal yang sama, dimana pioderma paling banyak ditemukan pada rentang umur 1-4 tahun dimana ditemukan 23 kasus $(43,4 \%)$ dari total 53 kasus. $^{10}$

Usia pra-sekolah dan sekolah memang memiliki faktor predisposisi yang memudahkan terkena pioderma. ${ }^{18}$ Karena pada usia-usia tersebut, anak mulai bereksplorasi dengan lingkungan dan memiliki keingintahuan yang tinggi. Proses belajarnya yang melibatkan alam sekitar seperti bermain dengan tanah dan air memberikan ruang bagi bakteri patogen untuk masuk. Apalagi anak-anak usia tersebut belum memahami pentingnya kebersihan diri. Oleh sebab itu, perhatian orang tua sangat dibutuhkan untuk mengontrol kebersihan diri anak agar tidak jatuh sakit tanpa mengekang keinginannya untuk belajar.

Jenis-jenis pioderma yang menyerang anak (Tabel 4), dengan prevalensi dari yang terbanyak adalah impetigo krustosa $(39,47 \%)$, folikulitis $(21,05 \%)$, dan yang paling sedikit adalah erisipelas sebanyak (0\%). Penelitian yang dilakukan Department of Microbiology, Gajra Raja Medical College, India oleh Gandhi mengemukakan hal yang sama dimana impetigo merupakan jenis pioderma terbanyak yang ditemukan, diikuti dengan folikulitis, furunkel, dan karbunkel. ${ }^{17}$ Penelitian Rizani di RS Al-Islam Bandung mendapatkan jenis pioderma terbanyak adalah impetigo kontangiosa atau krustosa $(53,5 \%) .{ }^{19}$ Penelitian yang dilakukan oleh Pangow tahun 2012 di Poliklinik Kulit dan Kelamin RSUP Prof. Dr. R. D. Kandou Manado juga menunjukkan impetigo sebagai jenis pioderma terbanyak yang ditemukan. ${ }^{10}$

Data mengenai distribusi terapi pioderma pada anak di Poliklinik Kulit dan Kelamin RSUP Prof. Dr. R. D. Kandou Manado periode tahun 2013-2015 (tabel 5) menunjukkan terapi paling banyak yang digunakan adalah terapi kombinasi, yaitu terapi yang menggabungkan antibiotik sistemik dan antibiotik topikal, yakni sebanyak 84 pasien $(73,68 \%)$, diikuti pemberian antibiotik topikal saja sebanyak 18 pasien $(16,67 \%)$ dan antibiotik sistemik sebanyak 10 pasien $(9,65 \%)$.

Pada tabel 6 menunjukkan antibiotik sistemik yang paling banyak digunakan pada anak adalah antibiotik golongan eritromisin, yaitu sebanyak $74 \quad(67,5 \%)$ kasus, diikuti dengan sefadroksil, cefixim, dan amoksisilin serta klindamisin yang penggunaannya paling sedikit. Penelitian sebelumnya di RSUP Prof. Dr. R. D. Kandou tahun 2012 oleh Pangow juga menunjukkan eritromisin sebagai antibiotik sistemik yang paling sering diberikan $(62,2 \%)^{20}$

Eritromisin merupakan pilihan alternatif bagi pasien dengan alergi penisilin. Eritromisin merupakan antibiotik golongan makrolid yang menghambat pertumbuhan bakteri dengan cara memblokir disolasi peptidyl t-RNA dari ribosom. $^{21}$

Walaupun penisilin merupakan antibiotik lini pertama, namun eritromisin merupakan antibiotik yang paling banyak digunakan. Hal ini mungkin karena eritromisin merupakan antibiotik alternatif apabila pasien mengalami alergi terhadap penisilin. Karena tes alergi memakan waktu dan biaya, maka eritromisin menjadi pilihan. Klindamisin juga dapat digunakan, tapi penggunaannya dibatasi karena efek samping yang lebih berat dibandingkan eritromisin.

Antibiotik topikal yang paling banyak digunakan (tabel 7) ialah asam fusidat $(52,63 \%)$, diikuti dengan mupirosin $(20,18 \%)$, dan gentamisin $(17,54 \%)$. Hasil yang sama ditemukan pada penelitian sebelumnya di Poliklinik Kulit dan Kelamin RSUP Prof. Dr. R. D. Kandou 
Manado tahun 2012, antibiotik topikal yang paling banyak digunakan pada anak dengan pioderma adalah asam fusidat. ${ }^{20}$ Asam fusidat merupakan salah satu antibakterial steroidal dengan efek bakteriostatik/ bakteriosidik terutama terhadap kuman Gram-positif. Penggunaan topikal asam fusidat menjadi salah satu pilihan terbaik sebagai antibiotik spektrum sempit. Karena asam fusidat aktif terhadap Staphylococcus aureus dan digunakan sebagai antibakteri topikal untuk infeksi kulit dan jaringan lunak. Asam fusidat telah menunjukkan permeabilitas kulit yang baik dan potensi alergi yang rendah. ${ }^{21,22}$

\section{SIMPULAN}

Berdasarkan penelitian mengenai pioderma pada anak di RSUP Prof. Dr. R.D. Kandou Manado periode tahun 20132015 dapat disimpulkan jumlah pasien kasus baru pioderma pada anak sebanyak 114 kasus, dengan terbanyak pada jenis kelamin laki-laki, kelompok umur 1-4 tahun, dan jenis pioderma impetigo krustosa. Terapi yang paling sering diberikan ialah pemberian terapi kombinasi antara antibiotik sistemik dengan topical yaitu eritromisin dan asam fusidat.

\section{SARAN}

Kelengkapan dalam pengisian status pasien sangat diperlukan guna menunjang pendataan yang lengkap, akurat dan informatif dan proses pengumpulan dan penyimpanan catatan rekam medik harus diperhatikan.

Edukasi pada masyarakat terutama para orang tua perlu ditingkatkan agar upaya kuratif, preventif, dan promotif dapat terlaksana dengan baik.

\section{DAFTAR PUSTAKA}

1. Sherwood L. Introduction to human physiology. Eighth edition. West Virginia University: Department of Physiology and Pharmacology School of Medicine West Virginia University; 2015. p. 479-81.

2. Wasitaatmadja SM. Anatomi Kulit-Faal Kulit. Dalam: Djuanda A, penyunting. Ilmu Penyakit Kulit dan Kelamin. Edisi keenam. Jakarta: Fakultas Kedokteran Universitas Indonesia; 2010. h. 3-7.

3. Boediardja S. Infeksi kulit pada bayi dan balita. Dalam: Trihono PP, Djer MM, Sjakti HA, Hendrarto TW, Prawitasari T, penyunting. Best practices in pediatrics. Jakarta: Ikatan Dokter Anak Indonesia Cabang DKI Jakarta; 2013. h. 46-59.

4. James WD, Berger TD, Elston DM. Andrew's diseases of the skin: clinical dermatology. 12 ed. Philadelphia: Elsevier Saunders; 2015. p.245-84.

5. Bowen AC, Mahé A, Hay RJ, Andrews RM, Steer AC, Tong SYC, et al. The Global Epidemiology of Impetigo: A Systematic Review of the Population Prevalence of Impetigo and Pyoderma. Journal. 2015;3-10.

6. Dewi KD. Penelitian retrospektif pioderma pada anak di Instalasi Rawat Inap Kesehatan Kulit dan Kelamin RSUD Dr. Soetomo Surabaya. Berkala Ilmu Kesehatan Kulit dan Kelamin. 2009; 21:185-90.

7. Azizah F. Frekuensi penyakit kulit di RS Karitas Sumba Barat Daya September 2014. Frekuensi penyakit kulit. 2014;2:147-50.

8. Laksmi Dewi BAAA, Dhana Saputra IPK, Rusyati LM, Bratiartha MD, Adiguna MS. Profil Pioderma di Poliklinik Klinik dan Kelamin RS Sanglah Denpasar Periode Januari 2006-Desember 2008. Penatalaksanaan pioderma terkini. PERDOSKI. 2014;41:85-90.

9. Harahap J. Pola infeksi kulit pada anak di Poliklinik Kulit dan Kelamin RSUP Prof. Dr. R.D Kandou Manado tahun 2009-2011 [Skripsi]. [Manado]: Fakultas Kedokteran UNSRAT; 2013.

10. Pangow CC. Profil Pioderma Pada Anak di Poliklinik Kulit dan Kelamin RSUP Prof. Dr. R. D. Kandou Manado Periode Januari-Desember 2012. [Skripsi]. [Manado]: Fakultas Kedokteran UNSRAT; 2015.

11. Permenkes $28 / 2014$. Daftar Penyakit Yang Ditanggung BPJS Kesehatan. Januari 2014 (cited 2016 November 10). 
Available from: http://www.bpjskis.info/2015/09/daftar-penyakityang-ditanggung-bpjs.html

12. Santos MM, Amaral S, Harmen SP, Joseph HM, Fernandes JL, Counahan ML. The prevalence of common skin infections in four districts in Timor-Leste: a cross .sectional survey. BMC Infectious Diseases Journal. 2010;61:1-6.

13. Hazarika N. A Clinico-Epidemiological Study of Pyoderma in Children. Nat.J.Res.Com.Med. 2012;1:178 241.

14. Kalu EI, Wagbatsoma V, OgbainiEmovon E, Nwadike VU, Ojide CK. Age and sex prevalence of infectious dermatoses among primary school children in a rural SouthEastern nigerian community. Pan Afr Med J. 2015;20:182.

15. Oyedeji OA, Okeniyi JA, Ogunlesi TA, Onayemi O, Oyedeji GA, and Oyelami OA. Parental Factors Influencing the Prevalence of Skin Infections and Infestations Among Nigerian Primary School Pupils. The Internet Journal of Dermatology. 2006;3(2):1531-3018.

16. Amoran OE, Runsewe-Abiodun OO, Mautin AO, Amoran IO. Determinants of dermatological disorders among school children in Sagamu, Nigeria. Educational Research. 2011;2(12):1743-8.

17. Gandhi S, Ojha AK, Ranjan, Neelima. Clinical and Bacteriological Aspects of Pyoderma. N Am J Med Sci. 2012;4:492-5.

18. Komba EV, Mgonda YM. The spectrum of dermatological disorders among primary school children in Dar es Salaam. BMC Public Health. 2010;10:765-70.

19. Rizani FA, Djajakusumah TS, Sakinah RK. Angka Kejadian, Karakteristik dan Pengobatan Impetigo di RS AlIslam Bandung. Prosiding pendidikan dokter. 2013;1009-15.

20. Goldsmith LA, Katz SI, Gilchrest AB, Paller SA, Leffell JD, Wolff $\mathrm{K}$. Fitzpatrick's Dermatology in General Medicine. 8th ed. United States of America: McGraw Hill; 2008. p.2128-47.

21. Long BH. Fusidic acid in skin and softtissue infections. Acta Derm Venereol. 2008;216:14-20.

22. Musmade P, Tumkur A, Trilok M, Bairy KL. Fusidic acid - topical antimicrobial in the management of staphylococcus. Int J Pharm Pharm Sci. 2013;5(4):381-90. 